\title{
Non-formal adult education coordinators as developers of educational activities and community interaction
}

\author{
Irena Zemaitaityte ${ }^{1, *}$ and Alina Petrauskiene ${ }^{1}$ \\ ${ }^{1}$ Mykolas Romeris University, Educational Science and Social Work Institute, Vilnius, Lithuania
}

\begin{abstract}
The growing importance of communities and community interaction is witnessed by the growing interest in these areas: in the emphasis on community development and in the need to bring educational and social services closer to local communities, both at the level of the European Union and at the political level of each of its member countries. Analyzing the community interactions active involvement in community functions, concern and trust in its people, and a look into the future are emphasized. The choice of the research methodology was determined by the aim of the research - to reveal the functions of non-formal learning coordinators of adult learning in municipalities as those of the developers of learning and community developers through their work experience. The analysis of the data highlighted the role of coordinators as community activators and community developers, bringing together adult learning groups, involving young people, gymnasium students, and volunteers in the implementation of training, through local non-formal education providers.
\end{abstract}

Key words - non-formal adult education, coordinators of adult education, community.

\section{Introduction}

The growing importance of communities and the idea of community are reflected in the evergrowing attention they attract: both the European Union and each of its members emphasize, on a political plane, the idea of community development, and the need to advance non-formal education closer to local communities. The goal of creating an effective lifelong learning system set in the "Lithuania 2030" strategy is also reflected in the State Education Strategy for 2013-2022 [1].

Analysing the community building in the society, the active involvement of the population in community activities, growth of care and mutual trust are emphasized [2, 3]. Bringing up community gives feelings of belonging, identity, emotional connection, and well-being. By experiencing and perceiving a sense of community, people adapt better, keep in touch with others, feel the social and spiritual support of those around them more strongly, and pursue higher goals. A strong sense of community acts as a protection against threats, and

\footnotetext{
*Corresponding author: irene@mruni.eu
} 
helps to overcome life changes [4]. Although this century in Lithuania saw a lot of changes - technology, mobility, independence, there is still felt a lack of sense of community [5].

In Grigas' opinion [6], the importance of community activities in fostering the culture of public citizens, promoting its accessibility, and meeting the cultural needs of the people of the community is related to the very rapid changes taking place both in the world and in Lithuania. A change not only provides individuals with new opportunities, but also poses certain challenges, making it sometimes difficult to grasp the alternating meaning, to engage in creative activities, and to formulate personal, family, and community goals. Researchers $[7,8]$ consent that one of the most important components of the community activities is related to learning. Non-formal learning provides opportunities for community members to upgrade their status and advance in the proficiency of a subject perception. Non-formal adult learning enables an individual to meet cognitive needs along with the improvement of the acquired education, and at the same time, learning promotes the pursuit of strategies for cognition of the world and personality and self-improvement. According to Žemaitaityte [8], non-formal adult education is described as a driving force that creates the future. It enables adults to take responsibility for their future and forms new social relationships, a new stage in the development of a democratic society.

The success of a community function lies in its openness, the ability to learn from its experiences, smooth adaptability to changing living conditions, and reception of innovations. This can be achieved if adults living in the community share the same values, trust each other and understand the goals of the community. Successful integration of individuals into the most active social life is possible only through purposeful community activities [9].

The aim of the article is to reveal the experience of Lithuanian non-formal adult education coordinators in developing learning activities and a sense of community.

In order to achieve the aim of the research, the following problem framing questions are raised: How do municipal coordinators implement NAE operational strategies in local communities and what difficulties do they encounter? How is community building strengthened through the implementation of NAE?

\section{Research methods}

The choice of the qualitative research methodology was determined by the aim of the research. For the qualitative research, the focus group method was chosen, reflecting with the study participants their work experience [10]. Article 8 part 2 of the Law on Non-formal Adult Education and Continuing Education of the Republic of Lithuania [11] obliges municipalities to prepare an action plan for non-formal and informal adult education and to appoint a coordinator for its implementation. Twelve Lithuanian non-formal adult education coordinators (10 women and 2 men) from different Lithuanian municipalities with 2-10 years of experience in planning, organizing, and coordinating adult non-formal education services participated in the study 2020.

The participants in the study signed an informed consent form, by which they confirmed their voluntary participation in the study, and the researchers were obliged to ensure the confidentiality of personal data.

At the stage of data analysis, the discussion record was transcribed. The result of data transcription is a text, which was deemed to be analysed by the qualitative content analysis [12] - a creative thinking process to decode the meanings in the text, understand and identify the situation and development perspectives. 


\section{Results}

\subsection{Strategies promoting participation of population in non-formal adult education and community building}

Increasing the learning opportunities of the population. The analysis of the content of the interview focus group participants' data allowed to highlight the coordinators' efforts and aspirations to involve as diverse a group of local people as possible in non-formal adult education. Coordinators recognize that promoting lifelong learning requires a coherent, long-term strategy that results in a long-term outcome, recognizing the acceptance and rejection reactions of the population. “... everything takes time, we were working consistently for ten years $<\ldots>$ for urging (collecting) them (residents) <...> now we have the result ... We encountered all reactions: I like it, I don't like it ..." The result of a long-term consistent coordinators' work is the increasing involvement of the groups of older population in lifelong learning and employment activities. It includes both actively involved in the labour market and the unemployed, attracting volunteers from various regional city university programs, strategies for seeking funding from the municipal budget. "Our city university works according to programs, we have 18 programs with permanent lecturers, and they are volunteers (lecturers), the ones we choose, and the municipality has given us some funds ..."

Another proven training development strategy is to invite residents to learn IT technologies in local gymnasium classrooms with the help of gymnasium teachers. However, ensuring the long-term participation of training participants is not easy ("but sometimes it's hard to get people together"). Therefore, it is important to constantly adjust the schedules of training cycles to find convenient times for working participants, and make them suitable for residents to come to training places at weekends. "In adult education, if the age group is 28-40, they would be working, raising children, so at best training is at the weekend..."

In other cases, the learning strategies of long-term population groups, when the strategies are recognized by learners as popular and attractive and in search of new opportunities to meet the learning needs of all those who want to learn, are gradually stabilizing. "We no longer fit in the art studio three times a week, the ceramics groups are full and overcrowded..."

Maintaining organizational links with the Third Age University helps municipal coordinators to involve older people in the university's training and educational activities. " $<$...> It is somewhat easier in the city when the word passed, and we no longer control the flows. Last year we didn't know what to do anymore, they keep calling and asking - I'm talking about the Third Age here now - please accept me, their kids are calling: my grandmother might not dare, she need to be involved. We saw that we need more people to organize that involvement, so we determined that there are several faculties, and then those people (third age) enrol in those faculties." The coordinators noted that learning opportunities for older people stretch when a Third Age University becomes attractive due to the variety of training and employment activities on offer, guarantees of the activity's regularity, and when older people are given the opportunity to negotiate a potentially attractive student fee. " $<\ldots>$ we say, Third Age University students are true students because there is no alternative to attendance here $\langle\ldots\rangle$ they attend and we issued certificates that they completed a one-year course of a faculty. When they come next year, they pay a lower fee, this is a plus." Joint educational and employment activities of the local community and the Third Age University participants are organized, which attract large groups of people who want to participate. "We do joint events, external educational trips $<\ldots>$ it attracts a lot of local people."

Activation of local NAE service providers and learning communities is an ongoing work of coordinators to facilitate the different learning needs of different population groups, from line dance groups to health discussions " $<\ldots>$ of course, then we find partners ... the 
Public Health Office .... very good, because it already meets those needs and the kind of training it already wants...".

Coordinators bring together public organizations such as "Officers' Chamber" (Karininku Ramove) "we started making friends with the soldiers, because Ramove is such an organization there ...", and teachers' academy by encouraging them to involve different groups in the community to learn together, and to create learning communities. "I really like when communities are formed as a Teachers' Academy, as soon as qualified teachers no longer want to cooperate, we have brought together a Teachers' Academy and connected community to them ..."

The analysis of the research data revealed the strategy of the coordinators as community activators for volunteer-trainers in order to motivate less active community members to organize for the implementation of some useful educational activity. Coordinators also note that in some municipalities, where there are no staff coordinators, there is a lack of focus on supporting local community activity and initiatives, explaining the needs of the population and "igniting" activities, finding and training volunteers, setting up coordination groups, sharing information " $<\ldots>$ there should be paid posts in municipalities to develop NAE, dedicated to this function solely... And that person would do the observation, gathering needs, what we have just said here, see in which eldership the communities are active, in which less active, how to establish activities there..."

Activating and mobilizing communities for the ongoing implementation of NAE are activities recognized by the coordinators. "This is where the activities of the coordinators are, there are endless activities that could be carried out, there is something to do, planning ... "

The analysis of the research data reveals the perspective of developing reflective community in older adult learning groups. According to the focus group participants, when implementing non-formal education attractive to the population, it is important to create and maintain community of people by organizing events, trainings, discussions, reflecting on the value of educational activities, applicability in real life or in perspective. "In adult education, that communion is very important when people gather, I go to plain airs myself, summer meetings, when we are together in discussions, reflections, endless attention to reflections on where what we do can be used, and not that we act. do and we break up."

For residents over the age of 65, leaving home for training is a first and foremost opportunity for meeting and communicating with others. Participation in educational activities, according to the focus group participants, helps older people feel safe and spend time meaningfully together, gain knowledge, get to know others. "This is so, our (coordinators") field is absolutely not related to qualifications, we strive for training for the harmony of human life, well-being... happiness...when people say it was fun, good, I met nice people, maybe I did not like the lecturer, but sitting next to me was a very great listener...". " $<\ldots>$ one of the priorities of non-formal adult education should be to create the safe environment that they (residents) say that we not only learn some things there, acquire knowledge, but also learn to communicate with other people... It is also learning." An aspect that promotes adult learning is the creation of safe environment for learning and learning from each other, where it is important for training participants to maintain a comfortable emotional environment for discussion or conversation. "It's important for people to capture a little bit of what people are saying, that a safe emotional environment is very important for people in those trainings, communication and meeting new people is very important..."

According to the focus group participants, the strategy of promoting the learning community of volunteer young people from local gymnasium students and seniors finds its justification in organizing foreign language and computer literacy trainings for seniors. In this way, the needs of older people who want to study are met when there is a lack of funds to pay for the work of hired lecturers. Focus group participants, on the other hand, noticed that 
the involvement of young high school students in senior education creates beautiful and informal relationships between the generations. Seniors thank young people for their efforts in high school with their own knitted socks or pastries "It is a very good experience, it has paid off for us, because we do not have the funds for universities, we have great needs for learning foreign languages, computer literacy, we have started to invite gymnasium students to volunteer for help. Wonderful, those grandmothers knit socks for those high school students and bake, such connection, a beautiful attitude and the action is taking place."

Coordinators also organize activities to which older adults are invited to volunteer, observe and participate in competitions and Olympiads organized by young people. The seniors then interact with the youth, having coffee together and sharing their impressions. Older adults are precisely the group in the community that is happy to get involved if they are invited to take part in meaningful actions and support coordinators' initiatives. "We invite seniors, because we have competitions, Olympiads, we ask them to volunteer to be observers, to invigilate and check cheating. Then those volunteers feel very important, to promote volunteering we agree with the cafe to encourage volunteering, we give a voucher of some 2 EUR to have coffee or tea in the city cafe. "

Study participants acknowledge that Dissemination of NAE learning outcomes in the community is a publicly expressed appreciation of learning outcomes in order to bring community members closer together. According to the focus group participants, the strategy of attracting community groups to the educational or employment activities of the NAE is organized by public presentation of learning outcomes - products, inviting, for example, friends, relatives, neighbours, others to the church or exhibition, and so on. The participants of the survey admit that: "It is very important to broadcast and show everyone, to enjoy the results...." "...I will tell you how we attract. When we have a clay / art studio, we have exhibitions all over the area once a year, and we now have about 25-27 women, and their relatives and friends come to greet them." "Thus, like that our art studio, we did an exhibition, we did it all the time in the library, we drew angels for a year and came up with the idea of having an exhibition in the church. Before Christmas, when the whole church is full of angels, it is also very good for everyone to visit, such good emotions. You really need to think, analyse how to act." Thus, it is important to notice the learning outcomes of the population, present them in various public spaces, libraries, churches of the city or local community, where members of the community visit and can see the product created by their relatives or acquaintances in the course of learning.

\section{Discussion}

Currently, the development of adult non-formal education in Lithuania is implemented by the Lithuanian municipalities, which plan appropriate funding resources and delegate the implementation of educational activities to municipal coordinators [11]. It is recognized that initiating and implementing educational activities in the adult community requires a professional specialist who should be able to mobilize people for learning, create an atmosphere of community, guarantee the reduction of hostility and mistrust, encourage community members to work together and learn from each other [3]. It is believed that Lithuanian municipal coordinators have a favourable environment for the development of activities - they have opportunities to cooperate with centres, libraries, museums, and other state and non-governmental organizations with experience in non-formal adult education. Coordinators can use or create Advisory Councils to improve their activities, expand partnerships and work with partners to address relevant issues of adult learners, engage in municipal strategic planning processes [13]. In Lithuania, the aim is to delegate more and more operational functions to adult non-formal education coordinators, although at the same time the status and functions 
of municipal coordinators are not defined in legal documents, therefore, specialists do not have clear responsibilities, they face significant additional workload and pressure from local municipal administration and politicians. Coordinators often feel alone and powerless in the face of the Non-formal Adult Education and Continuing Education Development Program for 2016-2023 [14], the implementation of the plan and overwhelmed by official responsibility $[13,15]$.

The analysis of the research data of this article revealed that the coordinators aim to implement strategies directed towards promotion of active participation of adults in non-formal education and community spirit. These strategies include planning and organizational functions of coordinators that increase the learning opportunities and diversity of the population through collaborative relationships with local, regional non-formal education providers, Third Age University communities, and lecturers, and the inclusion of youth and volunteers, high school students in senior curricula. However, the coordinators recognize that the promotion of lifelong learning of the adult population, the development of a reflective community of learners, and the dissemination of learning outcomes within the community require coherent planning and implementation strategies that bring long-term results. Therefore, in order to implement the state education strategy for 2013-2022, the Non-formal Adult Education and Continuing Education Development Program for 2016-2023, municipal strategic plans are required. There is the need for a greater support for coordinators in local government, clear definition of their functions and responsibilities, stable funding of the action plan, and collegial strategic issue resolution and autonomy in resolving day-to-day needs or issues.

\section{Conclusion}

The coordinators recognize implementation of non-formal adult education (NAE) in the country regions as a complex process, depending on the context of the local municipality and / or community and the development opportunities and perspectives of the coordinator's professional activities. The implementation of NAE as the planning and organization of adult learning activities is linked to strategies aimed at promoting the active participation of adults in non-formal education training programs and community spirit, in the coordinators' opinion. However, the implementation of these strategies in reality is complicated because of pressure from local politicians and administrations, the uncertainty of the coordinator's activities and functions and responsibilities, and the lack of a coherent long-term and professional perspective for coordinators. The analysis of the data highlighted the role of coordinators as community activators and community developers, bringing together adult learning groups, involving young people, gymnasium students, and volunteers in the implementation of training, through local non-formal education providers, Third Age University communities, and lecturers. For adults, training that meets their needs and allows them to see the benefits and applicability of learning outcomes in everyday life is attractive and promising.

\section{References}

[1] Lietuvos respublikos švietimo ir mokslo ministerija. Valstybiné švietimo 20132022 metu strategija. Vilnius, https://www.sac.smm.lt/wp-content/uploads/2016/02/ Valstybine-svietimo-strategija-2013-2020_svietstrat.pdf (2014) [accessed 19. August. 2021]

[2] J. Buškevičiūtè. Sumaniojo viešojo valdymo koncepcijos paieškos: skirtingų teoriniụ prieigụ kritinè analizè. Viešoji politika ir administravimas. Mokslo darbai 12(2), 359$371(2014)$ 
[3] G. Tolutienè, R.M. Andriekienè, R. Adomavičius. Parapijos kunigo andragoginès funkcijos bendruomenès veikloje, jụ plètros galimybès. Mokslo ir tikéjimo dialogai. Tiltai. Priedas: mokslo darbai 46(2), 52-76 (2016)

[4] A. Valackienè, E. Zalnieriūnienè. Bendruomenès dalyvavimas savivaldos procesuose: vietos bendruomenès atvejo analizè. TILTAI 2, 21-38 (2015)

[5] S. Nefas, V. Smalskys, V. Slapkauskas. Demokratija ir vietos bendruomenė Lietuvoje. Mykolo Riomerio universitetas (2011)

[6] R. Grigas. Bendruomeniškumo ir savivaldos Lietuvoje kaitos bruožai: istorioso_ne interpretacija. Vietos savivalda Lietuvoje. In_Konferencijos "Vietos savivalda ir bendruomenes Lietuvoje“" medžiaga.UDK 316.3(5)(06) (2010)

[7] M. Briedis, I. Leliūgienè, S. Nefas, R. Čiužas Bendruomenès ir suaugusiujų švietimas. Vilnius: Nacionalinis mokymụ centras (2013)

[8] I. Zemaitaityte. Empowerment of older people to participate in educational activities. Society, integration, education. Rêzeknes Augstskola II, 260-268 (2014)

[9] A. Aleksandravicius, J. Zukovskis. Kaimo bendruomeniu raida ir ju veiklos tikslai: siekiant darnumo visuomeneje. Management theory and studies for rural business and infrastructure development 1(25), 7-16 (2011)

[10] D.L. Morgan. Reconsidering the Role of Interaction in Analyzing and Reporting Focus Groups. Qualitative Health Research 20(5), 718 -722 (2010)

[11] Lietuvos respublikos Neformaliojo suaugusiųjų švietimo ir tęstinio mokymosi istatymas https://e-seimas.lrs.lt/portal/legalAct/lt/TAD/ce0399a00cd411e497f0ec0f 2b563356(2014) [accessed 5. August. 2021]

[12] V. Zydziunaite, S. Sabaliauskas. Kokybiniai tyrimai: principai ir metodai: vadovelis socialinių mokslų studijų programų studentams. Kaunas: VDU (2017)

[13] D. Penkauskienè. Neformaliojo suaugusiụjų švietimo ir tęstinio mokymosi koordinavimas savivaldybėse. Koordinatoriụ veiklos apžvalga, igyvendinant projektą, Suaugusiụjų švietimo veiksmų plano nacionalinis koordinavimas: Lietuva (Nr. 567447-EPP1-2015-1-LT-EPPKA3-ALAGENDA). Available: https://www.kpmpc.lt/kpmpc/wpcontent/uploads/2015/08/Koordinatori\%C5\%B3-veiklos-ap\%C5\%BEvalga.pdf (2017) [accessed 19. August. 2021]

[14] Neformaliojo suaugusiụjų švietimo ir tęstinio mokymosi 2016-2023 metụ plètros programa. Lietuvos respublikos vyriausybės nutarimas. Available: https://eseimas.lrs.lt/portal/legalAct/lt/TAD/b7f45490007711e6bf4ee4a6d3cdb874?jfwid= mmceo8f22 (2016) [accessed 7. August. 2021]

[15] A. Petrauskienè, I. Zemaitaitytè, Neformaliojo suaugusiųjų švietimo igyvendinimas šalies regionuose. Tyrimo ataskaita, igyvendinant projektą "Naujoji švietimo paradigma konkurencinemis sąlygomis” (kodas: 10.1.2-ESFA-K-917-03-0011). Available: https://svietimotinklas.lt/tyrimas/neformaliojo-suaugusiuju-svietimo-igyvendinimas-li etuvos-regionuose/(2020) [accessed 11. August. 2021] 